\title{
Index
}

Note: Page numbers in italic refer to figures. Page numbers in bold refer to tables.

ACAP see Arctic Contaminants Action Program

AEC see Arctic Economic Council

AEPS see Arctic Environmental Protection Strategy

Alaska

Alaska Native Claims Settlement Agreement (1971) 115

ban on offshore oil and gas development 55

birds' global migration routes 34,35 corporations of and AEC 53

distance from Russian coast 22, 27

Northern Forum launch 32

Aleut International Association 22, 42, 43, 50, 68, 116, 117

AMAP see Arctic Monitoring and Assessment Programme

AMEC see Arctic Military Environmental Cooperation

Arctic Athabaskan Council 22, 42, 43, 49-50, 68, 116, 119

Arctic Contaminants Action Program (ACAP) working group 80-81, 99-100, 113-114, 119

\section{Arctic Council}

'Arctic 5' coastal states

Arctic strategy 63-65

club status of $62-63,66-67,69$, 81,128

and Ilullissat Declaration (2008) 40, $66,67,84,95$ and increased regional activity 46 and UNCLOS 28, 72

'Arctic 8'

and AEC 53

club status of $13,59,62-63,69,81,128$

creation of Council 3, 59, 67-69, 103

as evidence of successful cooperation 124-125

formal procedures vs informal diplomacy 85

global vs regional issues 51

ministerial meetings $16-17,41,46$

Iqaluit meeting (2015) 40, 41, 42, 43-46, 56, 127

Kiruna meeting (2013) 39, 46-52, 57, 119, 127

Nuuk meeting (2011) 47, 48, 69, 118, 119

Observer Manual 47, 50, 63

project leadership by country 64-66, 65

secretariats

funding of main secretariat $65,71,72$

Indigenous Peoples Secretariat 65, 117 see also binding agreements; indigenous peoples; observer status (in Arctic Council); Russia, Arctic Council and Arctic diplomacy; science; task forces (of Arctic Council); working group (of Arctic Council) 
Arctic Economic Council (AEC) 26, 52-54, 57, 127

Working Groups (WGs) 53-54

Arctic Environmental Protection

Strategy (AEPS) 32-33, 58-59, 67-68, 103

Arctic Investment Protocol 26

Arctic Marine Shipping Assessment 7, 93, 119

Arctic Military Environmental Cooperation (AMEC) 80, 88

Arctic Monitoring and Assessment Programme (AMAP) working group 33, 51, 65, 92, 110-113, 121

Arctic National Wildlife Refuge (Alaska) 34, 35

Athabaskan peoples, Arctic Athabaskan Council 22, 42, 43, 49-50, 68, 116, 119

authority and non-state actors authority concept and chapter overview 2, 14, 104-105 authority in global governance 105 civic epistemology and authority 14 , 105, 107-108, 115, 120-123, 129-130

Baltic States, Council of Baltic Sea States (CBSS) 3, 77, 78, 125

Barents region

Barents cooperation 11, 32, 70, 77

Norway-Russia relations 28-29, 74

Bering Strait 21-22, 27

binding agreements

and Arctic Council task forces 65-66

chairmanship under Arctic Council 66-67, 66

Russia's role 65-66, 83, 94, 98, 102,129

specific agreements

Oil Spill Pollution and Response (2013) 40, 44-45, 98

Scientific Cooperation (2017) 98, 102

Search and Rescue (2011) 44, 98, 102

biodiversity $52,55-56,84$

black carbon 99, 119, 122

Task Force for Action on Black Carbon and Methane 45 business

AEC 26, 52-54, 57, 127

commercial actors 24-26, 32, 57

see also sustainable development

CAFF see Conservation of Arctic Flora and Fauna

Canada

and AEPS 59, 67, 68

and Arctic Council

'Arctic 5' and club status 62, 67

'Arctic 5' and increased regional activity 46

focus on economic issues 103

funding of Indigenous Peoples Secretariat 65

Iqaluit meeting (2015) 42, 44

Kiruna meeting (2013) and Asian states' observer status 46 , 47, 49, 51

project leadership role 65

and AEC 53

Arctic strategy 63

ban on offshore oil and gas development 55

Canadian Arctic 86

and Ilullissat Declaration (2008) 67

and international maritime law 25-26

'oil and gas industry and environment' debate 56

and RAIPON 90

and Russia's continental-shelf claim 96

CBSS see Council of Baltic Sea States

Central Arctic Ocean fisheries treaty 132

China

Arctic Council observer status 6, 38, $46,47,48,50,51,63$

polar map 34, 38, 48

Chukotka 20, 21, 22, 86

cities $25,77,83,86-88,92,102$

civic epistemology 14, 105, 107-108, $115,120-123,129-130$

climate change $39,47-48,49,52,54$, $60-61,114$

global warming 54, 132

see also United Nations Framework

Convention on Climate Change

(UNFCCC) 
club status $13,59,62-63,66-67,69$, 81,128

see also status-seeking politics coastal states ('Arctic 5')

Arctic strategy 63-65

club status of 62-63, 66-67, 69, 81,128

and Ilullissat Declaration (2008) 40, $66,67,84,95$

and increased regional activity 46

and UNCLOS 28, 72

Cold War

Arctic as military theatre 27-28, 40

and indigenous Arctic 21, 43

and International Geophysical Year 30

and provision of 'public goods' 58

scientific cooperation restrained by 29,30

colonialism 23-24

commercial actors 24-26, 32, 57

see also business

conservation

vs sustainable development $52,54-57$, 91-92, 97, 127

Conservation of Arctic Flora and Fauna (CAFF) working group 33, 51, 55-56, 65

contamination

during Soviet-era 80-81, 88-89, 95, 99-100

see also Arctic Contaminants Action Program (ACAP)

Convention on International Trade in Endangered Species of Wild Flora and Fauna (CITES) 29

Convention on the Conservation of Migratory Species 29

Council of Baltic Sea States (CBSS) 3, $77,78,125$

Crimea, Russia's annexation of (2014) $12,38,40-41,74-75,96,99$, 100-101

critical geopolitics 3, 4, 12, 39, 57

Denmark (Kingdom of Denmark, Greenland and Faroe Islands) and AEPS 68

and Arctic Council

'Arctic 5' and increased regional activity 46 funding of Indigenous Peoples

Secretariat 65

indigenous peoples'

representation 116

Kiruna meeting (2013) and

Asian states' observer status

46, 48-49

project leadership role 65

and AEC 53

Arctic strategy 64

and EU policy on the Arctic 71

'oil and gas industry and environment' debate 56

and Russia's continental-shelf claim 96

see also Greenland

DEW Line see Distance Early Warning

diplomacy (DEW) Line

and geopower 4-5

inter-city paradiplomacy 77

science diplomacy 14, 30, 31

see also Russia, Arctic Council and

Arctic diplomacy

Distance Early Warning (DEW)

Line 27-28

Emergency Prevention, Preparedness and Response (EPPR) working group 33, 94, 113

environmental issues

fragility of Arctic ecosystems 32

and indigenous peoples' organisations 22

and NGOs 19, 31

'oil and gas industry and environment' debate 56

and scientists $29-30$

and Soviet companies 25

see also Arctic Environmental

Protection Strategy (AEPS);

biodiversity; black carbon;

climate change; conservation;

contamination; pollutants;

Protection of the Arctic Marine

Environment (PAME) working

group; sustainable development

epistemic community 108

EPPR see Emergency Prevention,

Preparedness and Response

EU see European Union 


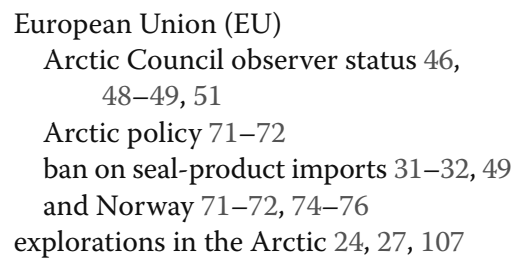

Faroe Islands see Denmark (Kingdom of Denmark, Greenland and Faroe Islands)

Finland

and AEC 53

and AEPS 59, 67-68

and Arctic Council

'Arctic 5' and club status 66-67

funding of Indigenous Peoples

Secretariat 65

Iqaluit meeting (2015) 41, 42

Kiruna meeting (2013) and Asian states' observer status 48

project leadership role 65 and Arctic Marine Shipping Assessment 93

Arctic strategy 64

fishing

Central Arctic Ocean fisheries treaty 132

fisheries-management cooperation between Norway and Russia 28-29

UN Fish Stocks Agreement 29

geopower 4-5, 57, 125-127, 131

globalisation 3-4

Greenland

'Arctic 5' and increased regional activity 46

conservation vs sustainable development debate 55,118

independence question 26

missionaries 24

see also Denmark (Kingdom of

Denmark, Greenland and Faroe Islands)

Greenpeace 31-32

Gwich'in Council International 22, 116

hierarchies in Arctic context

chapter overview 2, 13, 59-60, 81-82

global 'public goods' 58 hegemony vs hierarchy 59

hierarchy

and policy fields 60-61

and status-seeking politics 61

transactional vs structuring 62

hierarchy and Arctic governance

'Arctic 5' and club status 66-67, 81

'Arctic 8' and club status 62-63, 81

club status and 'resting great powers' 69

countries' Arctic strategies 63-64

leadership roles in Arctic Council projects $64-66,65$

leadership roles in chairmanship of binding agreements 66-67, 66

'resting great powers' 67-69, 81

hierarchy and people-to-people relations

growth of cross-border relations $76-77$

Russia and directly observed treatment, short course (DOTS) project 78,82

Russia-Canada indigenous leaders project $78-80,82$

Soviet-era contamination clean-up under ACAP 80-81

Norway and status-seeking

about status-seeking 61, 69-70

High North Strategy and 'knowledge power' 70-73, 76, 81

influence on EU's Arctic policy 71-72, 76

relationship with Russia 73-76

High North 6, 69-74, 75, 76, 107

IASC see International Arctic Science Committee

ICC see Inuit Circumpolar Council

Iceland

and AEC 53

and Arctic Council

'Arctic 5' and club status 66-67

Council membership and definition of Arctic 6

funding of CAFF and PAME secretariats 65

Kiruna meeting (2013) and Asian

states' observer status 48-49

project leadership role 65

Arctic strategy 64 
Ilullissat Declaration (2008) 40, 66, 67, 84, 95

ILO see International Labour

Organization's (ILO) resolution on indigenous people

indigenous peoples

about

colonialism 23-24

cross-state border connections 20-22

forced relocation and settlement policies 23

residential schools 23,30

seal hunting 31-32, 49

traditional knowledge 107, 123

and AEPS 52, 68

Arctic Council Permanent Participants

AMAP environment films 110-111

Asian states' observer status debate 49-50, 57

business/economic development 53

diplomatic interventions 14

and hierarchies 13, 61

high-level statements at Iqaluit meeting 42

indigenous organisations represented 22-23

Indigenous Peoples Secretariat 65, 117

'people's politics' and SDWG 109

post-2014 geopolitical tension $43,45-46$

working groups' independent diplomatic ties as problem 51

authority and role as Permanent Participants 14, 105

assessment with civic epistemology framework 121-123

case for Permanent Participant status 115-117

cross-border cooperation and post2014 Russia 118

economic development issues 118

holding states to account 118-120

representation and agenda-setting 117-118, 130

International Labour Organization's

(ILO) resolution on indigenous

people 115

indigenous peoples' organisations establishment of 22-24, 104-105

and other political actors 32

and policy fields 7

United Nations Forum for Indigenous

Peoples 23

International Arctic Science Committee

(IASC) 31-32

international law 25-26, 28-29,

$47,48,84$

see also United Nations Convention

on the Law of the Sea

(UNCLOS)

International Maritime Organization, Polar Code 7, 84

International Polar Year (IPY) 30, 93, 101, 103

International Whaling Commission 29

Inuit

Inuit polity 11, 18-19, 20-22, 106

Pan Inuit Trails project map 34, 37

seal hunting 31-32

Inuit Circumpolar Council (ICC)

and Arctic Council 33, 49, 57, 59, 116

and AEC 53

declaration on sovereignty in the Arctic (2015) 120

and indigenous internationalism 115

IPY see International Polar Year

Japan, Arctic Council observer status 46-48, 47

knowledge

and Arctic cooperation 105, 107

civic epistemology 14, 105, 107-108, $115,120-123,129-130$

and indigenous peoples 27, 107, 123

Norway as 'knowledge power' 70-73, 76, 81, 107, 128

see also science

migratory species $18,24,28-29$

map of global migration routes of

birds 34,35

military, the

Arctic Military Environmental Cooperation 80, 88

Cold War and Arctic as military theatre $27-28$

early state-military cooperative agreements $24,26-28$ 


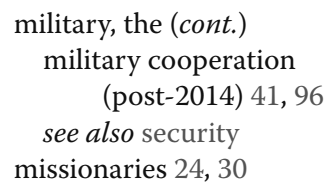

NATO see North Atlantic Treaty Organization

NEFCO see Nordic Environment Finance Corporation

NGO see non-governmental organisations

non-governmental organisations

(NGOs) 4, 7, 13, 19, 31-32, 51, $53,61,67,104-106$

non-state actors see authority and nonstate actors; indigenous peoples; non-governmental organisations (NGOs); science

Nordic Environment Finance Corporation (NEFCO) 64, 100

North Atlantic Treaty Organization (NATO) and Norway 74-75

Northern Forum 32

Northern Sea Route 87, 93, 97, 101

Northwest Passage 25-26

Norway

and AEC 53

and AEPS 68

and AMEC 80, 88

and Arctic Council

Asian states' permanent observer status issue $46,48,51$

chairmanship of binding agreements 66

funding of AMAP secretariat 65

funding of Indigenous Peoples

Secretariat 65

funding of main secretariat $65,71,72$

indigenous peoples' representation 116

'oil and gas industry and

environment' debate 56

project leadership role 65

science cooperation agreement 98

sustainable development vs conservation 97

and climate negotiations 60-61

and EU 71-72, 74-76
High North, definition of 6

as 'knowledge power' $70-73,76,81$, 107, 128

and NATO 74-75

and Russia

Barents Sea Delimitation

Agreement 28, 74

as 'bridge to Russia' 76, 128

fisheries-management cooperation 28-29

relationship with 73-76, 81

status-seeking politics 59, 61-63, 69-76, 81

observer status (in Arctic Council)

OGA see Oil and Gas Assessment

Asian states

applications for observer status 46

global framing and stated

interests 47,48

reactions of Arctic states 48-50

regional vs global framings $50-52$

China 6, 38, 46-48, 47, 50-51, 63

and club status 63

and Search and Rescue Task Force 51

Oil and Gas Assessment (OGA, 2007) 93, 101, 111-112

oil and gas industry

and AEC 54

Arctic Council recommendations 114

ban on offshore oil and gas development 55-56

Greenpeace's efforts to block activity 31

Soviet/Russian 25, 31, 53, 87

oil pollution

Exxon Valdez oil-spill incident 32

prevention and response 33, 40, $44-45,54,98,113$

PAME see Protection of the Arctic Marine Environment

Permanent Participants see indigenous peoples

Polar Bear Convention (1973) 28

Polar Code 7, 84

policy fields

and Arctic hierarchies 13, 59-61, $127-128$

and authority 106-107, 120-121 
and cross-border cooperation 6-8, 12,126

and informal diplomacy 84-86

transnational policy fields 105

pollutants 8, 29-30, 32-33, 68, 77, 132

see also oil pollution

power perspective

four propositions on power

malleable power relations 14,105 , 129-130

power, policy fields and hierarchy $13,59,127-128$

power relations and representations 12-13, 127

power, social constraints and diplomacy $13,84,128-129$

geopower 4-5, 57, 125-127, 131

globalisation and global governance 3-4

performance of power 4, 5, 14, 125-126

power relations and what/when/ where analytical steps 5-6

research methods and use of theory 14-17

scholarship review

disciplinary differences and main strands 8-9

discourse and representation 11-12

Regional Arctic institutions, legal frameworks, regimes 9-10

state and non-state actors' interests 10-11

success of Arctic cooperation 124-125

see also authority and non-state actors; hierarchies in Arctic context; representation, power politics of

Protection of the Arctic Marine Environment (PAME) working group 16, 33, 65, 91, 93

Putin, Vladimir

first presidency and Russia's northern policy $86-88$

second presidency's growing assertiveness 80, 84, 88, 103

RAIPON see Russian Association of Indigenous Peoples of the North

regime-theory literature 9-10

reindeer herding 21, 92, 116, 119 representation, power politics of chapter overview 2, 12, 38 examples of Arctic representations

Arctic as highway of movement 34

Chinese flattened polar map view 34, 38, 48

map from Pan Inuit Trails project 34,37

map of global migration routes of birds 34,35

map of North Circumpolar region 34,36

frame, concept and framing for policy action 12, 38-39

frame 1: cooperative Arctic

Arctic as zone of peace 39-41

following Russia's annexation of Crimea 41-46, 56

frame 2: global and regional framings

Asian states' interests 47, 48

Asian states' observer status on

Arctic Council 46-47

reactions of Arctic states 48-50

regional vs global framings 50-52, 56

frame 3: business in Arctic governance

AEC 52-54, 57

conservation vs sustainable development 54-56, 57

proposition on power, power relations and representations $12-13,127$

representations and maintaining power $56-57$

'resting great powers' 59, 67-69, 81, 128,132

Russia

and AEC 53

and AMEC 80, 88

and Arctic Council

archival memory project 102-103

'Arctic 5' and increased regional activity 46

'Arctic 5' club status 67

binding agreements 65-66, 83, 94, 98, 102, 129

chairmanship of binding agreements 66

and hierarchies in Arctic

diplomacy 13 


\section{Russia (cont.)}

Iqaluit meeting (2015) 42, 43-44

Kiruna meeting (2013) 39-40, 119

Kiruna meeting (2013) and Asian states' observer status 46, 47, 49, 50, 51, 57

North Pole trip (2013) 39-40

'oil and gas industry and environment' debate 56

project leadership role 65 science and AMAP's work 113

Arctic explorations (eighteenth century) 24

and Arctic Marine Shipping Assessment 93

Arctic natural resources, exploitation of 25

Arctic strategy 40, 63, 95-97

Chukotka 20, 21, 22, 86

continental-shelf claim 96

Crimea, annexation of (2014) 12, 38, $40-41,74-75,96,99-101$

Far North, definition of 6

icebreaker fee reduction 93, 101

and Ilullissat Declaration (2008) 67, 95

and Norway

Barents Sea Delimitation Agreement 28, 74

fisheries-management cooperation 28-29

relationship with $73-76,81$

oil and gas industry $25,31,53,87$

recentralisation of power to federal level 87

as 'resting great power' $59,67-69,81$, 128, 132

Soviet-era contamination clean-up 80-81, 88-89, 95, 99-100

Swedish-Russian North Pole expedition (2008) 39-40

as 'transitional' country 77, 94, 99, 128

Ukraine, 2014 interventions in 40, 45, $50,75,96,100$

US-Russian cooperation under ACAP 99

US-Soviet Union/Russia Barents Sea agreement 28

see also Putin, Vladimir; Russia, Arctic Council and Arctic diplomacy; Soviet Union
Russia, Arctic Council and Arctic diplomacy

chapter overview 2, 13, 83-84

norms of belonging, speaking and acting

hard and soft laws 84-85

informal diplomacy and policy

fields 84-86

proposition on power, social constraints and diplomacy 13 , 84, 128-129

Russian Arctic 86-89

Russia's engagement and Arctic diplomacy

Arctic governance as social space 100, 103

binding agreements 102, 129

coalition-building 102, 129

great powers' influence 102-103, 129

norms around procedure 101

taken-for-granted participation norm 101, 129

Russia's participation in Arctic Council (1997-2007)

assessment in terms of Arctic diplomacy 100-101

growing participation 90

Russian proposals 90-92, 94

Russia's responses to others' proposals 92-94

Russia's participation in Arctic Council (2007-2017)

assessment in terms of Arctic diplomacy 101-103

greater participation and key differences 95-97

high-level negotiations and binding agreements 98

Soviet-era contamination clean-up 99-100

see also Russia; Soviet Union

Russian Association of Indigenous

Peoples of the North (RAIPON)

$22,87,90,115-116,118,119-120$

Saami

cross-border Saami connections 21

and ILO's resolution on indigenous

people 115 
Saami Council 22, 42, 43, 116, 118-119

territories of and North-South political lines 34

scholarship review

disciplinary differences and main strands 8-9

discourse and representation 11-12

Regional Arctic institutions, legal frameworks, regimes 9-10

state and non-state actors' interests $10-11$

science

and Arctic Council 105

assessment with civic epistemology framework 121-123

science-policy interface downstream 108-109

when does science become policy 111-114

when do you know enough 114-115 who speaks for the Council 109-111, 130

and Arctic politics 107

and Russia's Arctic strategy 97

science diplomacy 14, 30, 31

Scientific Cooperation Agreement 98, 102

scientists

expert authority of 105-106

as political actors $29-30,108$

SDWG see Sustainable Development Working Group

seal hunting/products 31-32, 49, 51

Search and Rescue

Search and Rescue Agreement (2011) 44, 98, 102

Task Force 51, 98

security 10-11, 28, 44, 46, 49, 59, 88, 96

Singapore, Arctic Council observer status 46-48, 47

Snow, Water, Ice and Permafrost in the Arctic (SWIPA) assessment (2010) 112-113

South Korea, Arctic Council observer status 46-48, 47

Soviet Union

Arctic governance initiatives 59

Arctic natural resources, exploitation of 25

Chernobyl disaster 32
Cold War and Arctic as military

theatre 27-28

Cold War geopolitics 3

collapse of 77

communicable diseases 78

indigenous peoples 80, 115-116

Komsomolets nuclear submarine 32

Norway-Soviet Union/Russia

Barents Sea Delimitation

Agreement 28, 74

Polar Bear Convention (1973) 28

provision of 'public goods' 58

as 'resting great power' 59, 67-69, 81

Russian Arctic 86-89

Soviet-era contamination $80-81$, 88$89,95,99-100$

US-Soviet Cooperation in the Field of Environmental Protection agreement 30

US-Soviet relations and Diomede Islands 21

US-Soviet Union/Russia Barents Sea agreement 28

whale rescue incident (1988) 18, 19

zapovednik system 89

see also Russia; Russia, Arctic Council and Arctic diplomacy

status-seeking politics $61,69-70$

case of Norway 70-76

see also club status

sustainable development

and AEC 52-53

vs conservation 52, 54-57, 91-92, 97, 127

and permanent observer status applications 49

Sustainable Development Working Group (SDWG) 33, 91, 103, 109

Sweden

and Arctic Council

'Arctic 5' and club status 66-67

Iqaluit meeting (2015) 41, 42, 43

Kiruna meeting (2013) and Asian states' observer status 48

project leadership role 65

Arctic strategy 64

Saami's criticism of Swedish government 119

SWIPA see Snow, Water, Ice and Permafrost in the Arctic 


\section{Index}

task forces (of Arctic Council)

and binding agreements 65, 66, 119

by name

Action on Black Carbon and Methane 45

Arctic Marine Oil Pollution

Prevention 45, 54, 98

to Facilitate a Circumpolar Business Forum 53

Institutional Cooperation 47

Scientific Cooperation 98

Search and Rescue 51, 98

treaties see binding agreements; international law

UN see United Nations

UNCLOS see United Nations

Convention on the Law of the Sea

UNFCCC see United Nations

Framework Convention on

Climate Change

United Nations (UN)

Fish Stocks Agreement 29

indigenous internationalism 115

United Nations Convention on the Law of the Sea (UNCLOS) 28, 47-48, 63, 72, 84, 96, 124

United Nations Forum for Indigenous Peoples 23

United Nations Framework Convention on Climate Change (UNFCCC)

AMAP connections to 51

Conference of Parties

COP15, Copenhagen (2009) 14, 132

COP16, Cancun (2010) 14-15

COP21, Paris (2015) 8, 110, 132

United States (US)

and AEC 53

and AEPS 67-69

and AMEC 88

and Arctic Council

'Arctic 5' and increased regional activity 46

'Arctic 5' and club status 62-63, 67

chairmanship of binding

agreements 66 indigenous peoples'

representation 116

Iqaluit meeting (2015) 44

Kiruna meeting (2013) and Asian

states' observer status 46, 49, 51

project leadership role 65-66, 65

Scientific Cooperation 98, 102

Search and Rescue Agreement 102

and Arctic Marine Shipping

Assessment 93

Arctic strategy 64

ban on offshore oil and gas development 55

Cold War and Arctic as military theatre 27-28

and hierarchies in Arctic diplomacy 13

and international maritime law 25-26

and provision of 'public goods' 58

as 'resting great power' 59, 67-69, 81, 128,132

US see United States

US-Russian cooperation under ACAP 99

US-Soviet cooperation in the Field of Environmental Protection agreement 30

US-Soviet relations and Diomede Islands 21

US-Soviet Union/Russia Bering Sea agreement 28

whale rescue incident (1988) 18, 19

see also Alaska

WG see working group (of Arctic Council)

whales 18-19, 22, 29

working group (of Arctic Council)

issue of their semi-independence 51, 110-111, 121-123

see also individual working group entries

World Economic Forum 26

World Wide Fund for Nature (WWF) 31, 53

WWF see World Wide Fund for Nature 